\title{
Influence of composite restorative materials and light-curing units on diametrical tensile strength
}

\section{Influência do material restaurador e de aparelhos fotoativadores na resistência à tração diametral}

\author{
Maria Cecília Caldas Giorgi Tolosa* \\ Luís Alexandre Maffei Sartini Paulillo** \\ Marcelo Giannini** \\ Alex José Souza dos Santos*** \\ Carlos Tadeu dos Santos Dias ${ }^{* * * *}$
}

\begin{abstract}
The aim of this study was to evaluate the diametrical tensile strength (DTS) of three light-curing photo-activated composites with two different light curing units (LCU). Three types of dental restorative composites were used in this study: micro filled A110 (3M Espe); P60 (3M Espe) for posterior restorations, and micro-hybrid Charisma (Heraeus-Kulzer). The two LCUs were: halogen light (HAL) (Degulux, Degussa) and blue light emitting diode (LED) (Ultrablue, DMC). Resin composite specimens were inserted incrementally into a Teflon split mold measuring $3 \mathrm{~mm}$ in depth and $6 \mathrm{~mm}$ in internal diameter, and cured using either LCU $(\mathrm{n}=10)$. Specimens were placed into a dark bottle containing distilled water at $37^{\circ} \mathrm{C}$ for 7 days. DTS tests were performed in a Universal Testing Machine $(0.5 \mathrm{~mm} / \mathrm{min})$. Data were submitted to two-way ANOVA and Tukey's test. Results were (MPa): A110/HAL: $276.50 \pm 62.94^{\mathrm{a}} ;$ A110/LED: $306.01 \pm 65.16^{\mathrm{a}}$; P60/HAL: 568.29 $\pm 60.77^{\mathrm{b}}$ and P60/LED: 543.01 $\pm 83.65^{\mathrm{b}}$; Charisma/HAL: $430.94 \pm 67.28^{c}$; Charisma/LED: $435.52 \pm 105.12^{c}$. Results suggested that no significant difference in DTS was obtained with LCUs for the same composite. However, resin composite restorative materials presented different DTS.
\end{abstract}

DESCRIPTORS: Light emitting diode; Composite resins; Diametrical tensile strength; Mechanical properties.

RESUMO: O objetivo deste estudo foi avaliar a resistência à tração diametral (DTS) de três compósitos fotoativados com dois aparelhos de fotoativação (LCU). Os compósitos utilizados neste estudo foram: resina de micropartículas A110 (3M Espe); P60 (3M Espe), indicada para restaurações posteriores, e micro-híbrida Charisma (Heraeus-Kulzer). As fontes de luz foram: halógena (HAL) - Degulux (Degussa) e luz emitida por diodos (LED) - Ultrablue (DMC). As amostras foram confeccionadas através de dois incrementos inseridos em uma matriz de Teflon bipartida medindo $3 \mathrm{~mm}$ de profundidade e $6 \mathrm{~mm}$ de diâmetro interno e foram fotoativadas pelas LCUs $(\mathrm{n}=10)$. As amostras foram armazenadas dentro de recipientes escuros contendo água destilada a $37^{\circ} \mathrm{C}$ por 7 dias. O ensaio de DTS foi realizado com a Máquina de Ensaio Universal Instron com velocidade de $0,5 \mathrm{~mm} / \mathrm{min}$. Os dados obtidos foram submetidos à Análise de Variância e ao teste de Tukey. Os resultados foram (MPa): A110/HAL: 276,50 $\pm 62,94^{\mathrm{a}}$; A110/

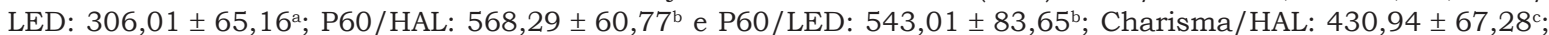
Charisma/LED: 435,52 $\pm 105,12^{c}$. Desta forma, os resultados indicaram que não houve diferença significativa de DTS em relação aos aparelhos para uma mesma resina. Entretanto, entre os materiais ocorreram diferenças significativas nos valores de DTS.

DESCRITORES: Diodos emissores de luz; Resinas compostas; Resistência à tração diametral; Propriedades mecânicas.

\section{INTRODUCTION}

Light-activated restorative resin composites have revolutionized operative dentistry becoming the most popular aesthetic materials. They offer many clinical advantages, such as control over the duration of light exposure to which the restoration is subjected, allied to the ease of manipulation and improvement of general properties ${ }^{3}$.

The most popular way of generating blue light today is by means of halogen-based light-curing units (LCU). However, halogen technology has

\footnotetext{
* Graduate Student; ${ }^{* *}$ Associate Professors; ***PhD Student - Department of Restorative Dentistry, School of Dentistry of Piracicaba, State University of Campinas.

**** Assistant Professor, Department of Statistical Mathematics, University of São Paulo.
} 
Tolosa MCCG, Paulillo LAMS, Giannini M, Santos AJS, Dias CTS. Influence of composite restorative materials and light-curing units on diametrical tensile strength. Braz Oral Res 2005;19(2):123-6.

showed some inconveniences, such as: halogen bulbs have a limited effective lifetime of approximately 100 hours and the bulb, reflector, and filter can degrade over time due to the high operating temperatures produced during the operating cycles, which results in the decrease of LCUs' curing efficacy. The clinical implication of this is that, with an aging LCU, light-activated dental materials may have poorer physical properties, leading to an increased risk of premature failure of restorations ${ }^{5}$.

To overcome the shortcomings of halogen-bulb visible LCUs, LED technology has been proposed to polymerize light-activated dental materials ${ }^{7}$. The advantage of blue LEDs is that they emit blue light in a narrow bandwidth that closely corresponds to the absorption peak of camphorquinone, a photo initiator commonly used in light-activated materials. Gallium nitride or blue LEDs emit blue light with a peak output at $460 \mathrm{~nm}$. Another advantage of LEDs is that they have an expected lifetime of several thousand hours, without significant degradation of their light emission properties over time ${ }^{13}$. Moreover, they require no filters to produce blue light, are very resistant to shock and vibration, and their relatively low power consumption make them suitable for portable use ${ }^{8}$.

The present study has determined the effect of two light curing units (halogen light and blue light emitting diode) on diametrical tensile strength (DTS) of three photo-activated dental restorative composites (microfilled, micro hybrid and packable resin for posterior restorations).

\section{MATERIALS AND METHODS}

The resin composites were tested to compare their DTS and irradiated with two visible LCUs: a blue light emitting diode (LED) (Ultrablue, DMC, São Carlos, Brazil) and a conventional halogen lamp (Degulux, Degussa Dental, Hanau, Germany) (Table 1). Three commercially available light-cured composite resin restorative materials, namely, Filtek A110 (3M Espe, St. Paul, MN, USA), Filtek P60 (3M Espe, St. Paul, MN, USA) and Charisma (Heraeus Kulzer, Wehrheim/Ts, Germany), A3 shade, were tested. These materials are described in Table 2.

Restorative composites were cured with both LCUs, forming six experimental groups $(n=10)$. Teflon split molds (Cometa S.A., Piracicaba, SP, Brazil) with $3 \mathrm{~mm}$ in depth and $6 \mathrm{~mm}$ in diameter were used to prepare the cylindrical specimens, which were incrementally built up in two layers. Unpolymerized composite material was placed inside the molds and cured for $20 \mathrm{~s}$. The second layer of restorative material was covered with a Mylar Strip (Jon, São Paulo, Brazil) and cured for $20 \mathrm{~s}$. The prepared specimens were stored in a

TABLE 1 - Light-curing units used to evaluate diametrical tensile strength of composites.

\begin{tabular}{l|c|c}
\hline \hline Light-curing unit & Type & Power density* \\
\hline DEGULUX & Halogen Lamp & $700 \mathrm{~mW} / \mathrm{cm}^{2}$ \\
\hline ULTRABLUE & LED & $190 \mathrm{~mW} / \mathrm{cm}^{2}$ \\
\hline \hline
\end{tabular}

*Measured according to the manufacturer's information. LED light emitting diode.

TABLE 2 - Composition of composite resins evaluated in this study.

\begin{tabular}{l|c|c|c}
\hline \hline \multirow{2}{*}{$\begin{array}{l}\text { Composite } \\
\text { Type }\end{array}$} & \multicolumn{2}{|c|}{ Composition } & $\begin{array}{c}\text { Filler particle } \\
\text { distribution } \\
\text { (\% weight) }\end{array}$ \\
\cline { 2 - 4 } $\begin{array}{l}\text { Filtek } \\
\text { A 110 } \\
\text { microfilled }\end{array}$ & $\begin{array}{c}\text { Bis-GMA } \\
\text { TEGDMA }\end{array}$ & silica & $56 \%$ \\
\hline $\begin{array}{l}\text { Filtek } \\
\text { P 60 } \\
\text { packable }\end{array}$ & $\begin{array}{c}\text { Bis-GMA } \\
\text { UDMA } \\
\text { Bis-EMA }\end{array}$ & $\begin{array}{c}\text { zirconia and } \\
\text { silica }\end{array}$ & $84 \%$ \\
\hline $\begin{array}{l}\text { Charisma } \\
\text { micro } \\
\text { hybrid }\end{array}$ & Bis-GMA & $\begin{array}{c}\text { barium } \\
\text { aluminum } \\
\text { fluoride glass }\end{array}$ & $80 \%$ \\
\hline \hline
\end{tabular}

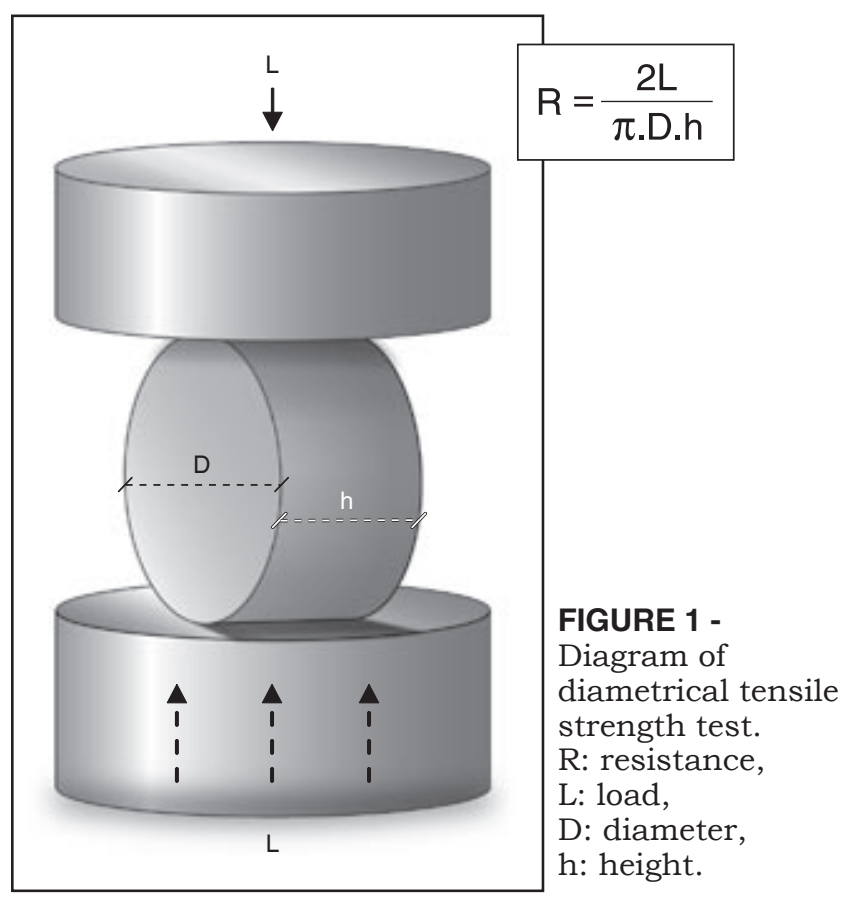


Tolosa MCCG, Paulillo LAMS, Giannini M, Santos AJS, Dias CTS. Influence of composite restorative materials and light-curing units on diametrical tensile strength. Braz Oral Res 2005;19(2):123-6.

TABLE 3 - Mean and standard deviation (SD) of DTS for experimental groups (MPa).

\begin{tabular}{l|c|c}
\hline \hline $\begin{array}{c}\text { Experimental } \\
\text { group }\end{array}$ & Mean $\pm \mathrm{SD}$ & Overall DTS \\
\hline A110/HAL & $276.50 \pm 62.94^{\mathrm{a}}$ & \multirow{2}{*}{$291.25 \pm 64.16^{\mathrm{a}}$} \\
\hline $\mathrm{A} 110 / \mathrm{LED}$ & $306.01 \pm 65.16^{\mathrm{a}}$ & \\
\cline { 1 - 2 } $\mathrm{P} 60 / \mathrm{HAL}$ & $568.29 \pm 60.77^{\mathrm{b}}$ & \multirow{2}{*}{$555.65 \pm 72.33^{\mathrm{b}}$} \\
\cline { 1 - 2 } P60/LED & $543.01 \pm 83.65^{\mathrm{b}}$ & \\
\hline CHARISMA/HAL & $430.94 \pm 67.28^{\mathrm{c}}$ & \multirow{2}{*}{$433.23 \pm 85.93^{\mathrm{c}}$} \\
\hline CHARISMA/LED & $435.52 \pm 105.12^{\mathrm{c}}$ & \\
\hline \hline
\end{tabular}

Means followed by different lower case letters are different by Tukey's test ( $\mathrm{p}<0.05)$. LED: light emitting diode. HAL: halogen light. DTS: diametrical tensile strength.

light-proof container with distilled water at $37^{\circ} \mathrm{C}$ for 1 week.

The diametrical tensile strength (DTS) test was performed using a Universal Testing Machine (Instron Corporation, Canton, MA) at a crosshead speed of $0.5 \mathrm{~mm} / \mathrm{min}$. Specimens were positioned vertically on the testing machine base and subjected to compressive load until failure (Figure 1). Mean DTS values were expressed in MPa and data were analyzed by two-way ANOVA (composite vs. LCU), followed by Tukey's test at the 0.05 level of significance.

\section{RESULTS}

Mean values and standard deviations of DTS for experimental groups are displayed in Table 3. Two way ANOVA indicated significant difference for the factor "composite resin $(p<0.0001)$ ". No significant difference was identified for the factor "curing unit $(\mathrm{p}=0.8812)$ " or for the interaction between factors $(\mathrm{p}=0.524)$.

Tukey's test showed that resin composites presented similar DTS when they were photocured by either halogen light or LED technology $(p=0.8812)$. However, composite resins presented different DTS among themselves. P60 restorative composite presented the highest DTS $(555.65 \pm 72.33 \mathrm{MPa})$, and A-110 microfilled resin, the lowest $(291.25 \pm 64.16 \mathrm{MPa})$. DTS for Charisma micro-hybrid resin composite was $433.23 \pm 85.93 \mathrm{MPa}$.

\section{DISCUSSION}

In this study, a LED unit was used to cure dental composite resins, and its performance was compared to a conventional halogen light. Results showed that there was a significant difference only for the composite resin factor. The higher mean of DTS was observed for the packed composite (P60), and the lower mean for the microfilled composite (A110), which shows the influence of composite components on DTS.

An increase of filler content in resin matrix improves mechanical properties of dental composites, such as: compressive and diametrical tensile strength $\mathrm{s}^{4}$, abrasion resistance, coefficient of thermal expansion and modulus of elasticity ${ }^{11}$. Filtek A110 and Filtek P60, both from the same manufacturer, use colloidal silica and zirconium/silica, respectively. Difference is observed in the weight percentage of the filler. A 110 shows a filler content of $56 \%$, and P60 presents a filler content of $84 \%$, resulting in higher DTS. Charisma is a micro hybrid composite with $80 \%$ weight of filler content and showed intermediate DTS.

Mechanical properties of P60 indicate this composite is appropriate for posterior restorations. A110 presents lower filler content, which gives characteristics of excellent esthetic properties and lower mechanical properties to this material. For these reasons, A110 is generally used in anterior restorations.

Monomeric composition affects the degree of conversion of dental composites and the quality of the restoration. The composition of $\mathrm{P} 60$ includes Bis-GMA, Bis-EMA and UDMA. Bis-EMA and UDMA are molecules of higher molecular weight with best properties for visible light diffusion ${ }^{9}$. BisEMA is a hydrophobic monomer, homologous to Bis-GMA, used to minimize water sorption of the resin matrix, maintaining the bonding between the filler particle and resin matrix and preventing its degradation ${ }^{11}$. The change of Bis-GMA or TEGDMA for UDMA results in an improvement of mechanical properties (tensile and flexure strength). UDMA has been reported to have lower viscosity and the flexibility of urethane linkage, which may improve the toughness of resin composites containing this monomer. Besides, there are indications that higher degrees of conversion are obtained with urethane dimethacrylates when compared with Bis-GMA $^{11}$. Beyond a possible effect of the degree of conversion, the increase in tensile strength may be associated with the ability of urethane linkage to form hydrogen bonds in the copolymer, which presumably results in a restricted sliding of polymer segments in relation to each other ${ }^{1}$.

The results have also indicated that there was no statistically significant difference in diametrical tensile strength of composites polymerized with ei- 
Tolosa MCCG, Paulillo LAMS, Giannini M, Santos AJS, Dias CTS. Influence of composite restorative materials and light-curing units on diametrical tensile strength. Braz Oral Res 2005;19(2):123-6.

ther light-curing unit, although the LED LCU presented approximately one third of halogen LCU irradiance. This fact can be explained by the spectral distribution of emitted light of both LCUs and by the range of absorption of camphorquinone. Both units produce their maximum irradiance in different regions of the spectrum - the emission peak of LED LCU at $465 \mathrm{~nm}$, and the peak of halogen LCU at $497 \mathrm{~nm}$. The light absorption of camphorquinone is at $467 \mathrm{~nm}$, which includes the LED peak ${ }^{6}$. However, if the initiator used absorbs outside the narrow emission range of the LED, the conversion degree might be compromised ${ }^{12}$. Photo initiators such as 1-phenyl-1,2-propanedione (with a peak absorption of $410 \mathrm{~nm}$ ), bisacylphosphine oxide or triacylphosphine oxide (with a peak absorption of 320 to $390 \mathrm{~nm}$ ) fall outside this range and will possibly present curing problems ${ }^{2}$.

The manufacturer should inform the initiator used in their material's composition so that dentists may be able to avoid this incompatibility problem. Therefore, assessment of LED and halogen LCU performances based on a comparison of their irradiances is not clear. Rather than a comparison of irradiance, it seems to be more helpful to compare the mechanical properties of composites cured with LED or halogen technology ${ }^{6}$.

\section{REFERENCES}

1. Asmussen E, Peutzfeldt A. Influence of UEDMA, BisGMA and TEGDMA on selected mechanical properties of experimental resin composites. Dent Mater 1998;14:51-6.

2. Burgess JO, Walker RS, Porche C, Rappold AJ. Light curing - an update. Compend Contin Educ Dent 2002;23(10):889-906.

3. Caughman WF, Rueggeberg FA, Curtis Jr JW. Clinical guidelines for photocuring restorative resins. J Am Dent Assoc 1995;126(9):1281-6.

4. Chung KH, Greener H. Correlation between degree of conversion, filler concentration and mechanical properties of posterior composite resins. J Oral Rehabil 1990;17:487-94.

5. Fan PL, Wozniak WT, Reyes WD, Stanford JW. Irradiance of visible light-curing units and voltage variation effects. J Am Dent Assoc 1987;115(9):442-5.

6. Jandt KD, Mills RW, Blackwell GB, Ashworth SH. Depth of cure and compressive strength of dental composites cured with blue light emitting diodes (LEDs). Dent Mater 2000;16(1):41-7.
Since the development of the high power blue $\mathrm{LED}^{10}$, this new technology has offered the opportunity to be used as an alternative source for curing composite materials. Its performance in this study suggests that its clinical application is feasible. However, further mechanical tests and clinical trials are required to validate the use of LED LCU for clinical use.

\section{CONCLUSION}

Results suggested that LCUs did not affect the DTS when the same composite was tested. Composite restorative materials presented different DTS, which showed that the filler content and monomer composition affect the properties of restorations.

\section{ACKNOWLEDGEMENTS}

The authors are indebted to the Department of Dental Materials, School of Dentistry of Piracicaba - Brazil, for allowing the use of their Universal Testing Machine. The LED curing-unit was supplied by Savatel Dental, Brazil.

7. Mills RW. Blue light emitting diodes - another method of light curing? Br Dent J 1995;178(5):169.

8. Mills RW, Jandt KD, Ashworth SH. Dental composite depth of cure with halogen and blue light emitting diode technology. Br Dent J 1999;186(8):388-91.

9. Moznner N, Salz U. New developments of polymeric dental composites. Prog Polym Sci 2001;26:535-76.

10. Nakamura S, Senoah M, Iwasa N, Nagahama S. Highpower InGaN single-quantum-well-structure blue and violet light-emitting diodes. Apply Phys Lett 1995;67(13):1868-70.

11. Peutzfeldt A. Resin composites in dentistry: the monomer systems. Eur J Oral Sci 1997;105:97-116.

12. Slilkas N, Eliades G, Watts DC. Light intensity effects on resin-composite degree of conversion and shrinkage strain. Dent Mater 2002;16:292-6.

13. Stahl F, Ashworth SH, Jandt KD, Mills RW. Lightemitting diode (LED) polymerization of dental composites: flexural properties and polymerization potential. Biomaterials 2000;21:1379-85. 